\title{
Inflammatory Bowel Disease and Risk of Osteoporotic Fractures: A Meta-Analysis
}

Diego F. Hidalgo ${ }^{1}$, Boonphiphop Boonpheng ${ }^{2}$, Jennifer Phemister ${ }^{3}$, Jessica Hidalgo ${ }^{4}$, Mark Young ${ }^{3}$

1. Geriatrics, Jackson Memorial Hospital / University of Miami, Miami, USA 2. Internal Medicine, East Tennessee State University, Johnson City, USA 3. Gastroenterology, East Tennessee State University, Johnson City, USA 4. Internal Medicine, San Francisco De Quito University, Quito, ECU

Corresponding author: Diego F. Hidalgo, dhidalgo014@gmail.com

\begin{abstract}
\section{Introduction}

Inflammatory bowel disease (IBD) and its complications have been well-established. The literature shows an association between IBD and decreased bone mineral density in the adult population. However, most studies have reported an association between IBD and osteoporosis, while the risk of fractures has not been wellstudied. The aim of this meta-analysis is to summarize the best available evidence regarding IBS and osteoporotic fractures.
\end{abstract}

\section{Methods}

A review of the literature using the MEDLINE and EMBASE databases was performed during November 2017. We included cross-sectional and cohort studies that reported the relative risks, odds ratios, and hazard ratios comparing the risk of developing osteoporotic fractures among patients with IBD patients, both ulcerative colitis (UC) and Crohn's disease (CD), versus patients without IBD as controls. The pooled odds ratio (OR) and $95 \%$ confidence interval (CI) were calculated using the generic inverse-variance method.

\section{Results}

After a review of the literature, seven studies fulfilled the eligibility criteria established during the analysis. A significant association was found between IBD and osteoporosis, with a pooled OR of 1.32 (95\% CI, 1.2 -

1.4). Low heterogeneity among the studies was found, $\mathrm{I}^{2}=42.3$. No publication bias was found using the Egger regression test $\mathrm{p}=0.18$. Sensitivity analysis showed that the inclusion of data on children by Kappelman et al. (2007) did not change the results.

\section{Conclusion}

A significant association between IBD and the risk of developing osteoporotic fractures was observed in this study. There is a $32 \%$ increased risk, which is consistent with different cohort studies previously done.

Received 09/13/2019

Review began 09/21/2019

Review ended 09/27/2019

Published 09/30/2019

๑) Copyright 2019

Hidalgo et al. This is an open access

article distributed under the terms of the Creative Commons Attribution License CC-BY 3.0., which permits unrestricted use, distribution, and reproduction in any medium, provided the original author and source are credited.
Categories: Endocrinology/Diabetes/Metabolism, Internal Medicine, Gastroenterology

Keywords: inflammatory bowel disease (ibd), osteoporosis, bone mineral density, malabsorption, osteoporotic fractures, ulcerative colitis, crohns disease

\section{Introduction}

Inflammatory bowel disease (IBD), including ulcerative colitis (UC) and Crohn's disease (CD), plays an important role as risk factors for the development of osteoporosis and osteoporotic fractures [1]. The risk of developing osteoporosis ranges between $17 \%$ to $41 \%$ [2]. The prevalence of both spinal trabecular and peripheral cortical osteoporosis is increased in IBD patients. In addition, there is an increased severity of clinical osteoporosis in young, amenorrheic women [3].

With the increased risk of developing osteoporosis, patients are at a greater risk of suffering osteoporotic fractures. IBD patients can have an increased risk of fractures by $40 \%$ as compared to the general population, which affects their quality of life and increases their morbidity [4-5].

The mechanism of how IBD puts patients at an increased risk of developing osteoporosis and osteoporotic fractures is likely multifactorial. Often, steroids are prescribed to patients with IBD as treatment, and this can itself predispose patients to develop osteoporosis, however, the different studies that have been adjusted for glucocorticoid use have not reported a significant increase of osteoporosis in patients taking this medication [5]. This being said, it appears to be mechanisms that intrinsically affect bone metabolic activity in patients with IBD such as the chronic inflammatory state in IBD leading to bone loss through Tumor necrosis factor (TNF) alpha RANK/RANKL/osteoprotegerin system activation, which promotes osteoclastogenesis [5]. Another contributing factor often present is secondary hyperparathyroidism due to 


\section{Cureus}

the malabsorption of important nutrients like calcium and vitamin D [6].

The aim of this study is to summarize the best evidence correlating IBD patients with the risk of developing osteoporotic fractures versus control patients without IBD.

\section{Materials And Methods}

\section{Search strategy}

Two investigators (DH and BB) personally reviewed two databases, MEDLINE and EMBASE, during the month of November 2017. The search strategy included terms and synonyms for "IBD," "fractures," and "osteoporosis."

Apart from the two major databases used for this meta-analysis, an additional manual review of the references of selected, included articles was also performed. This study meets the criteria checklist in accordance with the preferred reporting items for systematic reviews and meta-analysis (PRISMA) statement.

\section{Selection criteria}

Any study, in order to be selected for this meta-analysis, had to fulfill the following parameters:

- Case-control, cross-sectional, or cohort studies published as original articles in the two major databases used. These studies should investigate the risk of developing osteoporotic fractures in patients with IBD, either CD or UC.

- Odds ratio (OR), relative risk (RR), or hazard ratio (HR) with $95 \%$ confidence intervals (CIs) or documentation and data enough to calculate the previous ratios were provided.

In order to evaluate the quality of each study, the investigators independently used the validated NewcastleOttawa quality assessment scale (Figure 1). This scale evaluated each study in terms of the selection of the participants, comparability between groups, as well as the ascertainment of the exposure of interest for case-control studies, and the outcome of interest for cohort studies [7]. 


\section{Cureus}

\section{NEWCASTLE - OTTAWA QUALITY ASS ES S MENT SCALE CASE CONTROL ST UDIES}

Note: A study can be awarded a maximum of one star for each numbered item with in the Selection and Exposure categories. A maximum of two stars can be given for Comparability.

\section{Selection}

1) Is the case definition adequate?

a) yes, with independent validation $\boldsymbol{\square}$

b) yes, eg record linkage or based on self reports

c) no description

2) Representativeness of the cases

a) consecutive or obviously representative series of cases

b) potential for selection biases or not stated

3) Selection of Controls

a) community controls

b) hospital controls

c) no description

4) Definition of Controls

a) no history of disease (endpoint)

b) no description of source

\section{Compa ra bility}

1) Comparability of cases and controls on the basis of the design or analysis
a) study controls for
(Select the most important factor.)

b) study controls for any additional factor $\boldsymbol{\square}$ (This criteria could be modified to indicate specific control for a second important factor.)

\section{Exposure}

1) Ascertainment of exposure

a) secure record (eg surgical records) $\square$

b) stru ctured interview where blind to case/control status

c) interview not blinded to case/control status

d) written self report or medical record only

e) no description

2) Same method of ascertain ment for cases and controls

a) yes $\square$

b) no

3) Non-Responserate

a) samerate for both groups $\square$

b) non respon dents described

c) rate different and no designation

\section{FIGURE 1: Newcastle-Ottawa quality assessment scale}

Adapted from "The Ottawa Hospital, Research Center," by Wells G, Shea B. 2014, http://www.ohri.ca/programs/clinical_epidemiology/oxford.asp

\section{Data extraction}

A Microsoft Excel (Microsoft Corporation, Redmond, Washington, US) data collection form was used to summarize the most relevant information obtained from these studies. This table contained the first author's last name, the country where the study was conducted, year of publication, demographics, the NewcastleOttawa quality assessment scale, the total number of participants, characteristics of the participants, the method used to diagnose IBD, the method used to determine fractures, adjusted effect estimates with 95\% $\mathrm{CI}$, and covariates that were adjusted in the multivariate analysis (Table 1).

\begin{tabular}{|c|c|c|c|c|c|c|c|}
\hline & $\begin{array}{l}\text { Bernstein et al. } \\
2000[5]\end{array}$ & $\begin{array}{l}\text { Edwards et al. } \\
2002 \text { [8] }\end{array}$ & Kappelman et al. [9] & Targownik et al. $2013[10]$ & $\begin{array}{l}\text { Tjeerd-Pieter et al. } 2003 \\
\text { [11] }\end{array}$ & $\begin{array}{l}\text { Ferencz et al. } \\
2002[12]\end{array}$ & Tsai et al. 2014 [13] \\
\hline Country & Canada & USA & USA & Canada & United Kingdom & Hungary & China \\
\hline
\end{tabular}




\section{Cureus}

\begin{tabular}{|c|c|c|c|c|c|c|c|}
\hline Study design & $\begin{array}{l}\text { Population-based } \\
\text { cohort study }\end{array}$ & $\begin{array}{l}\text { based } \\
\text { inception } \\
\text { cohort study }\end{array}$ & Cross-sectional & $\begin{array}{l}\text { Population-based cohort } \\
\text { study }\end{array}$ & $\begin{array}{l}\text { Primary care-based } \\
\text { nested case-control } \\
\text { study }\end{array}$ & $\begin{array}{l}\text { Population- } \\
\text { based cohort } \\
\text { study }\end{array}$ & $\begin{array}{l}\text { Population-based } \\
\text { cohort }\end{array}$ \\
\hline Year & 2000 & 2002 & 2010 & 2013 & 2003 & 2002 & 2014 \\
\hline Number of participants & 6027 & 238 & 1242 & 1230 & 231,778 & 110 & $\begin{array}{l}3141 \text { IBD patients and } \\
12,564 \text { age- and sex- } \\
\text { matched controls }\end{array}$ \\
\hline Participants & $\begin{array}{l}\text { Patients with } \\
\text { inflammatory } \\
\text { bowel disease in } \\
\text { the University of } \\
\text { Manitoba IBD } \\
\text { Database (n } 5 \\
6027 \text { ) were } \\
\text { matched to } 10 \\
\text { randomly selected } \\
\text { persons in the } \\
\text { general population } \\
\text { without } \\
\text { inflammatory } \\
\text { bowel disease ( } 5 \\
60270 \text { ) by year, } \\
\text { age, sex, and } \\
\text { postal area of } \\
\text { residence. }\end{array}$ & $\begin{array}{l}238 \text { patients } \\
\text { with a } \\
\text { diagnosis of } \\
\text { Crohn's } \\
\text { Disease based } \\
\text { on clinical } \\
\text { records. }\end{array}$ & $\begin{array}{l}733 \text { children with CD, } 488 \\
\text { with UC, and } 3287 \\
\text { controls. }\end{array}$ & $\begin{array}{l}\text { we included only the first } \\
\text { DXA examination that any } \\
\text { patient underwent between } \\
1997 \text { and } 2008 \text {. Subjects in } \\
\text { the MBMDD who were also } \\
\text { cases in the UMIBDED and } \\
\text { were diagnosed with IBD } \\
\text { before the date of the DXA } \\
\text { examination were } \\
\text { considered to have IBD, } \\
\text { whereas all other subjects } \\
\text { were considered to not have } \\
\text { IBD. Subjects with IBD were } \\
\text { also further sub-classified as } \\
\text { having CD or UC. }\end{array}$ & $\begin{array}{l}\text { Case patients were } \\
\text { permanently registered } \\
\text { Patients aged } 18 \text { years } \\
\text { and older who had a } \\
\text { fracture at any site in } \\
\text { their medical records. } \\
\text { Control patients were } \\
\text { adults without a history } \\
\text { of fracture in their } \\
\text { medical records. }\end{array}$ & $\begin{array}{l}110 \text { IBD } \\
\text { patients, } 80 \text { ( } \\
\text { UC) and } 30 \\
\text { (Crohn's } \\
\text { disease) were } \\
\text { involved in the } \\
\text { study. } 110 \\
\text { patients with } \\
\text { suspected } \\
\text { MBD due to } \\
\text { other reasons } \\
\text { and regularly } \\
\text { referred for } \\
\text { BMD } \\
\text { measurement } \\
\text { were used for } \\
\text { comparison. }\end{array}$ & $\begin{array}{l}\text { Patients aged } 20 \text { years } \\
\text { and older with IBDs, } \\
\text { namely UC (ICD-9-CM } \\
\text { code 556) and CD (ICD- } \\
\text { 9-CM codes 555.0- } \\
555.2 \text { ), who were newly } \\
\text { diagnosed between } \\
2000 \text { and 2010, and } \\
\text { refer to them as the IBD } \\
\text { cohort. For each IBD } \\
\text { patient, four } \\
\text { comparisons were } \\
\text { randomly selected from } \\
\text { the pool of participants } \\
\text { without IBD and } \\
\text { osteoporosis. }\end{array}$ \\
\hline $\begin{array}{l}\text { Mean age of } \\
\text { participants in years }\end{array}$ & 39 & $\begin{array}{l}33.4+/-16.3 \\
\text { years (range, } \\
4-84 \text { years). }\end{array}$ & 15 & 61 & 68.4 & $35.2 \pm 17$ years. & 47 \\
\hline Percentage of female & NA & $54 \%$ & $45 \%$ & $76 \%$ & $28 \%$ & $50 \%$ & $47 \%$ \\
\hline Diagnosis of IBD & $\begin{array}{l}\text { Clinical records } \\
\text { from Manitoba IBD } \\
\text { database obtained } \\
\text { from Manitoba } \\
\text { Health } \\
\text { Administrative } \\
\text { Database. ICD } 9 \\
\text { CM codes were } \\
\text { used to identify } \\
\text { patients with } \\
\text { either Crohn's } \\
\text { disease or } \\
\text { ulcerative colitis. }\end{array}$ & $\begin{array}{l}\text { Complete } \\
\text { medical } \\
\text { records of each } \\
\text { candidate case } \\
\text { were retrieved } \\
\text { and reviewed } \\
\text { for the } \\
\text { diagnosis of CD } \\
\text { between } 1940 \\
\text { and } 1993 \text { from } \\
\text { Olmsted } \\
\text { County } \\
\text { residents. }\end{array}$ & $\begin{array}{l}\text { Patients with at least } \\
\text { three health care } \\
\text { contacts, on different } \\
\text { days, associated with ICD } \\
\text { codes for IBD. Or patients } \\
\text { with at least one claim for } \\
\text { CD or UC and at least } \\
\text { one pharmacy claim for } \\
\text { any of the following } \\
\text { medications: mesalamine, } \\
\text { olsalazine, balsalazide, } \\
\text { sulfasalazine, 6- } \\
\text { mercaptopurine, } \\
\text { azathioprine, infliximab, } \\
\text { adalimumab, or enteral } \\
\text { budesonide. }\end{array}$ & $\begin{array}{l}\text { Medical Records from The } \\
\text { University of Manitoba IBD } \\
\text { Epidemiologic Database } \\
\text { (UMIBDED) that mentioned } \\
\text { the ICD codes for IBD, } \\
\text { Crohn's and ulcerative } \\
\text { colitis. }\end{array}$ & $\begin{array}{l}\text { Severity of IBD was } \\
\text { assessed using } 2 \\
\text { factors: a history of } \\
\text { general practitioner } \\
\text { visits for symptoms of } \\
\text { IBD (diarrhea, } \\
\text { abdominal pain, anemia, } \\
\text { rectal bleeding, or } \\
\text { weight loss) and } \\
\text { hospitalization for a } \\
\text { gastrointestinal disorder } \\
\text { in the } 12 \text { months before } \\
\text { the index date. In } \\
\text { addition, the use of } \\
\text { medication for the } \\
\text { treatment of IBD was } \\
\text { examined }\end{array}$ & NA & $\begin{array}{l}\text { Records review of } 20 \\
\text { years and older patients } \\
\text { with IBDs, namely UC } \\
\text { (ICD-9-CM code 556) } \\
\text { and CD (ICD-9-CM } \\
\text { codes } 555.0-555.2) \text {, } \\
\text { who were newly } \\
\text { diagnosed between } \\
2000 \text { and } 2010 \text {, and } \\
\text { refer to them as the IBD } \\
\text { cohort. }\end{array}$ \\
\hline $\begin{array}{l}\text { Diagnosis of } \\
\text { Fractures/Osteoporosis }\end{array}$ & $\begin{array}{l}\text { Using the } \\
\text { Manitoba Health } \\
\text { administrative } \\
\text { database for } \\
\text { hospital discharge } \\
\text { abstracts (using } \\
\text { ICD-9-CM codes } \\
\text { for hip fracture, } \\
\text { also outpatient } \\
\text { visits for rib, spine } \\
\text { and wrist/forearm } \\
\text { codes. }\end{array}$ & $\begin{array}{l}\text { Radiologist's } \\
\text { reports about } \\
\text { Fractures of the } \\
\text { hip, spine, or } \\
\text { distal forearm } \\
\text { that resulted } \\
\text { from minimal or } \\
\text { moderate } \\
\text { trauma in } \\
\text { patients } 35 \\
\text { years or older } \\
\text { were } \\
\text { considered to } \\
\text { represent } \\
\text { osteoporotic }\end{array}$ & $\begin{array}{l}\text { Claims for fractures } \\
\text { occurring at each of the } \\
\text { following sites using ICD- } \\
9 \text { diagnosis codes: ankle, } \\
\text { clavicle, foot, hand, } \\
\text { humerus, femur, radius, } \\
\text { skull, tibia, and vertebral. }\end{array}$ & $\begin{array}{l}\text { A subject is considered to } \\
\text { have DXA-defined } \\
\text { osteoporosis if the T score is } \\
\text { less than_2.5. }\end{array}$ & $\begin{array}{l}\text { Registered patients } \\
\text { aged } 18 \text { years and older } \\
\text { who had a fracture at } \\
\text { any site in their medical } \\
\text { records. }\end{array}$ & $\begin{array}{l}\text { BMD of the } \\
\text { lumbar spine, } \\
\text { hip, and } \\
\text { proximal } \\
\text { forearm were } \\
\text { measured by } \\
\text { Prodigy (GE } \\
\text { Lunar) } \\
\text { densitometer, } \\
\text { and Z-scores } \\
\text { were } \\
\text { evaluated. } \\
\text { Previous low- } \\
\text { trauma } \\
\text { fractures were }\end{array}$ & $\begin{array}{l}\text { The IBD cohort and the } \\
\text { non-IBD cohort were } \\
\text { followed up until } \\
\text { osteoporosis was } \\
\text { diagnosed or censored } \\
\text { because of mortality, } \\
\text { loss to follow-up, } \\
\text { withdrawal from the } \\
\text { insurance system, or } \\
\text { December } 31,2010 \text {. } \\
\text { Osteoporosis was } \\
\text { diagnosed according to } \\
\text { a T score with >-2.5 SD. }\end{array}$ \\
\hline
\end{tabular}




\section{Cureus}

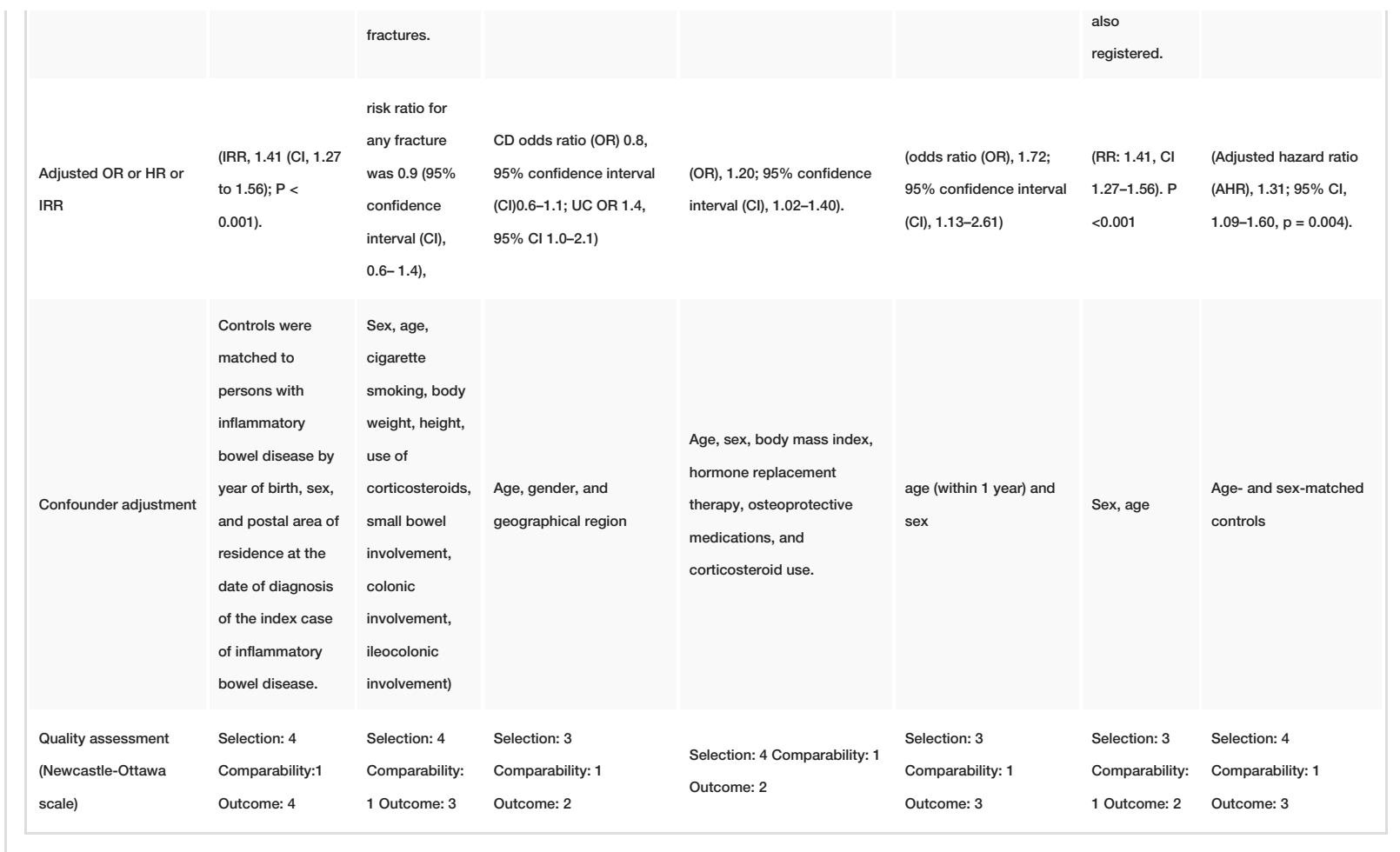

TABLE 1: Characteristics of studies included in the analysis.

Abbreviation: IBD: Inflammatory Bowel Disease, UC: Ulcerative Colitis, CD: Crohn's Disease, DXA: Dual X-Ray Absorptiometry, MBD: Metabolic Bone Disease, BMD: Bone Metabolic Density, UMIBDED: University of Manitoba IBD Epidemiologic Database

To ensure accuracy, all investigators performed the data extraction process independently. Any data discrepancy was also resolved by referring back to the original articles.

\section{Statistical analysis}

Data analysis was performed using Review Manager 5.3 software from the Cochrane Collaboration (London, United Kingdom). Adjusted point estimates and standard errors from the individual study were combined using the generic inverse variance method of DerSimonian and Laird, which assigned the weight of each study based on its variance [14]. In light of the possible high between-study variance due to different study designs and populations, we used a random-effect model rather than a fixed-effect model. Cochran's $Q$ test and I2 statistic were used to determine the between-study heterogeneity. A value of I2 of $0 \%-25 \%$ represents insignificant heterogeneity, greater than $25 \%$ but less than or equal to $50 \%$, represents low heterogeneity, greater than $50 \%$ but less than or equal to $75 \%$ represents moderate heterogeneity, and greater than $75 \%$ represents high heterogeneity [15].

\section{Results}

An advanced search yielded 7237 articles on Medline and 2171 articles on EMBASE. After the exclusion of 6550 articles that were duplicated, 2858 underwent a title and abstract review. A total of 2802 articles were excluded, as they were case reports, book articles, letters to the editor, or review articles without the information needed for the analysis, leaving 56 articles for a full-length article review. A total of 45 articles were dismissed at this time, as they did not report the outcome we were looking for. Two articles did not have comparators so they were also excluded. A total of seven studies were used for statistical analysis [16], five of them were cohort studies, one case-control study, and one cross-sectional study. The outlines of the literature review and study selection process is outlined in Figure 2. The clinical characteristics of each study and the quality assessment are described in Table 1. 


\section{Cureus}

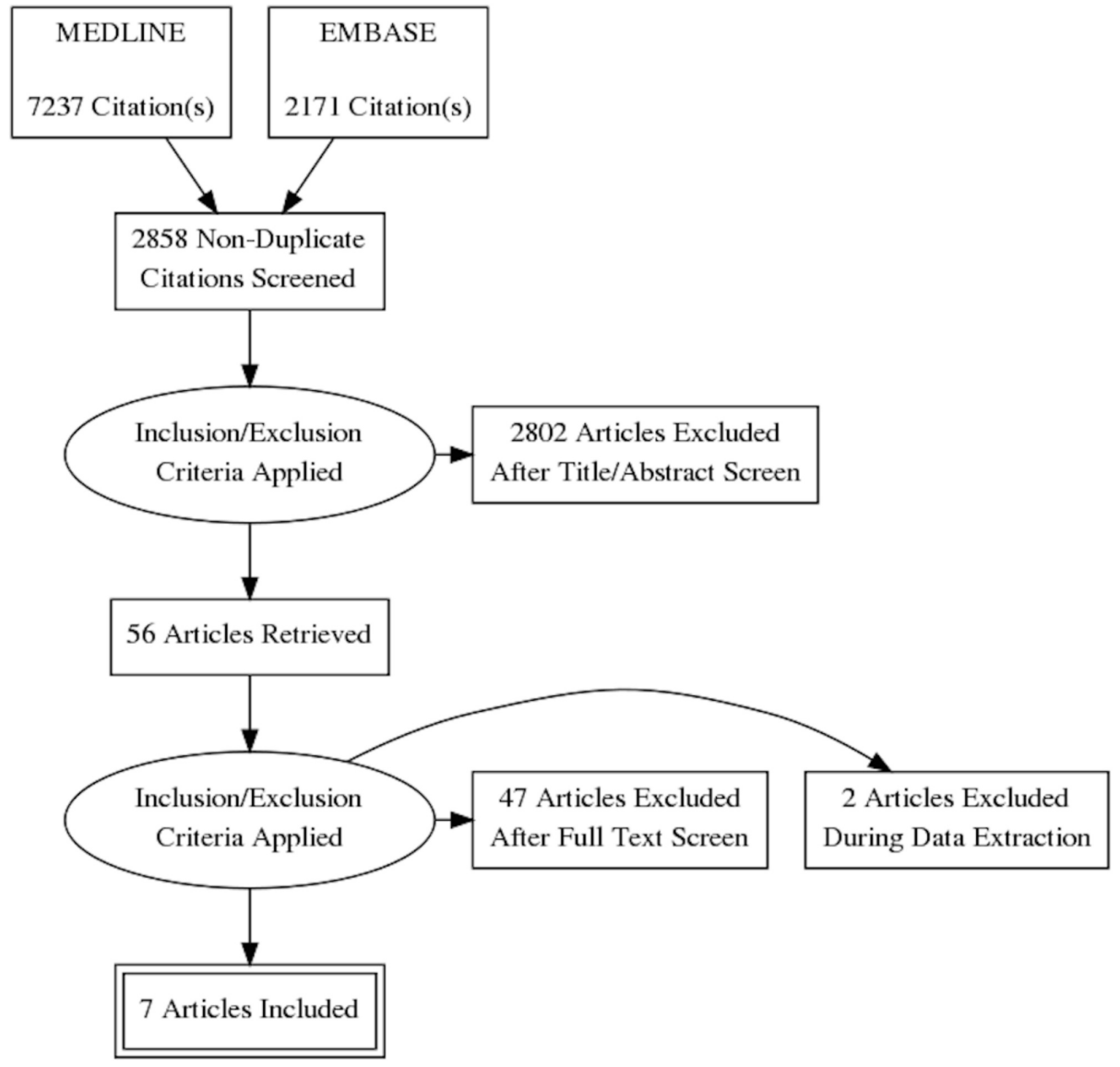

FIGURE 2: Search criteria and eligibility

The overall analysis found a higher risk of osteoporotic fractures in patients with IBD, either UC or CD, as compared with the control individuals who did not have IBD. The odds ratio (OR) was 1.32 (95\% CI: 1.20 1.45), $\mathrm{P}<0.001$, as shown in Figure 2. Sensitivity analysis showed that the inclusion of data on children by Kappelman et al. (2009) did not affect the results, as shown in Figure 3.

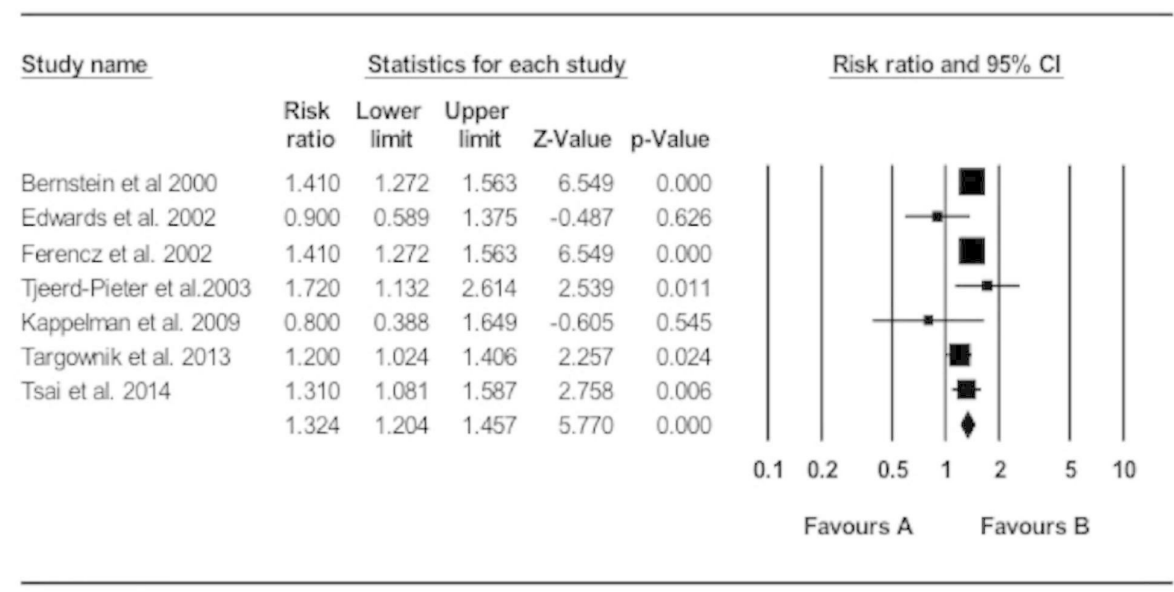

Meta Analysis

FIGURE 3: Relative risk and $P$ values

To measure heterogeneity among the studies, Cochran's Q test and I2 were calculated. The I2 calculated for this study was 42.3 , which represents low heterogeneity among the studies. 
The Egger regression test and funnel plots were used to assess publication bias [17]. Egger's regression test (P 0.18) did not show a publication bias. Funnel plots (Figure 4) were symmetrical, indicating low publication bias. The total number of studies were seven, which correlates with high power for this test.

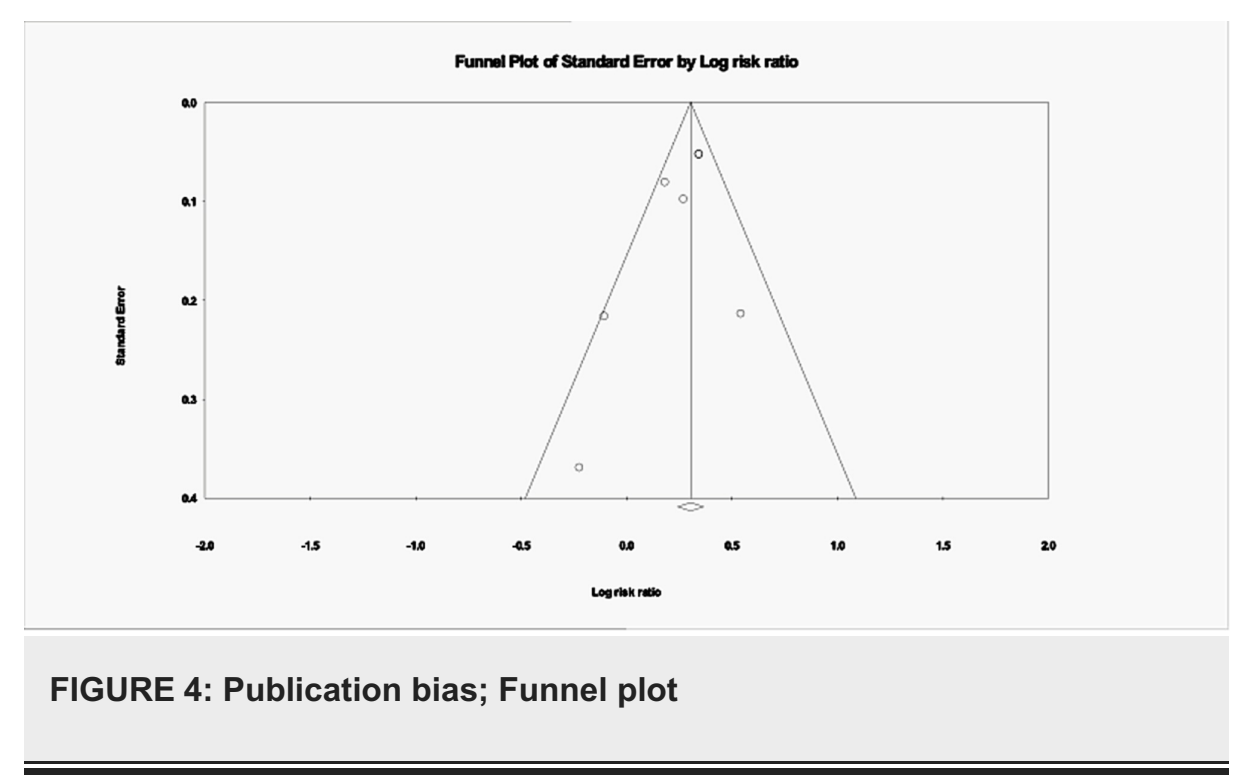

\section{Discussion}

This study is a meta-analysis to evaluate the risk of developing osteoporotic fractures among IBD patients. After evaluating a total of seven studies (cohort, case-control, and cross-sectional) that met the inclusion criteria, with a total population of 242,524 patients, we found that patients with IBD have a $32 \%$ increased risk of developing osteoporotic fractures.

This is the first meta-analysis that assesses the relationship between IBD and fractures. A lot of data has been obtained to assess the relationship between IBD and osteoporosis, which is defined as reduced mineral density. However, the risk for developing bone fractures is the one associated outcome that really has significant morbidity, mortality, and healthcare cost $[16,18]$.

This meta-analysis takes into consideration research studies done all over the world, including the USA, UK, Hungary, China, and others. It collects more than 200,000 patients and records. We included a study done by Kappelman et al. (2009) that took into consideration the pediatric population [9]. This study showed no increased risk of fractures in patients below the age of 20. Sensitivity analysis showed that the inclusion of this article in the pool of information did not have a big impact on the final outcome. These results confirm that the risk of osteoporotic fractures increases with age, and even patients with IBD tend not to show accelerated signs of bone disease until years after the disease has progressed [19].

We calculated the risk of fractures on IBD as a whole. We did not make any distinction between CD or UC, as some articles were just focused on CD while others included UC too. Further studies would be needed to evaluate the risk of fractures associated with the specific type of IBD.

The data used for this meta-analysis were matched for the use of corticosteroids. Steroids by themselves put patients at increased risk of fractures. The most significant effect of steroids $n$ the bones is inhibition of osteoblastic activity, which decreases bone formation. This inhibition in the number of osteoblasts is secondary not only to a decrease in the formation but also an increase in the death of mature osteoblasts. At the same time, glucocorticoids decrease the function of the remaining osteoblasts directly and indirectly through the inhibition of insulin-like growth factor I expression [20]. Since most IBD patients are or have been on steroids at some point of the disease, this could be a confounding factor. Direct standardization was used to adjust for this confounder.

After adjusting for the use of this medication, the decrease in bone mass and the increase of developing bone fractures was significant enough to confirm that an inflammatory state is enough to make changes to the bone metabolism.

A low I2 value on the statistical analysis suggests that the variation across studies is due to a low heterogeneity rather than chance.

More studies should be done to calculate the risk to develop fractures in the pediatric population since early identification, risk factors modification, and treatment could slow the risk of bone mass loss and improve morbidity in that specific population. 


\section{Conclusions}

A significant association between IBD and the risk of developing osteoporotic fractures was observed in this study. There is a $32 \%$ increased risk of developing osteoporotic fractures in patients with IBD as compared to individuals without IBD used as controls. There was no significant increase of osteoporosis in IBD patients taking corticosteroids after this variable was adjusted through direct standardization.

\section{Additional Information \\ Disclosures}

Human subjects: All authors have confirmed that this study did not involve human participants or tissue. Animal subjects: All authors have confirmed that this study did not involve animal subjects or tissue. Conflicts of interest: In compliance with the ICMJE uniform disclosure form, all authors declare the following: Payment/services info: All authors have declared that no financial support was received from any organization for the submitted work. Financial relationships: All authors have declared that they have no financial relationships at present or within the previous three years with any organizations that might have an interest in the submitted work. Other relationships: All authors have declared that there are no other relationships or activities that could appear to have influenced the submitted work.

\section{References}

1. Lima CA, Lyra AC, Mendes CMC, Lopes MB, Coqueiro FG, Rocha R, Santana GO: Bone mineral density and inflammatory bowel disease severity. Braz J Med Biol Res. 2017, 50:6374. 10.1590/1414-431X20176374

2. Ali T, Lam D, Bronze MS, Humphrey MB: Osteoporosis in inflammatory bowel disease . Am J Med. 2009, 122:599-604. 10.1016/j.amjmed.2009.01.022

3. Mundy GR: Osteoporosis and inflammation. Nutr Rev. 2007, 65:147-151. 10.1111/j.17534887.2007.tb00353.x

4. Compston J, Judd D, Crawley EO, et al.: Osteoporosis in patients with inflammatory bowel disease . Gut. 1987, 28:410-415. 10.1136/gut.28.4.410

5. Bernstein CN, Blanchard JF, Leslie W, Wajda A, Yu BN: The incidence of fracture among patients with inflammatory bowel disease. A population-based cohort study. Ann Intern Med. 2000, 133:795-799. 10.7326/0003-4819-133-10-200011210-00012

6. DRI dietary reference intakes for calcium and vitamin D . (2010). Accessed: August 2018: http://books.nap.edu/openbook.php?record_id=13050.

7. Stang A: Critical evaluation of the Newcastle-Ottawa scale for the assessment of the quality of nonrandomized studies in meta-analyses. Eur J Epidemiol. 2010, 25:603-605. 10.1007/s10654-010-9491-z

8. Edwards L, Crowson CS, Sandborn WJ, Tremaine WJ, O'Fallon WM, Melton LJ III: 3rd long-term fracture risk in patients with Crohn's disease: a population-based study in Olmsted County, Minnesota. Gastroenterology. 2002, 123:468-475. 10.1053/gast.2002.34779

9. Kappelman MD, Rifas-Shiman SL, Kleinman K, Ollendorf D, Bousvaroslow A, Grandlow RJ, Finkelstein JA: The prevalence and geographic distribution of Crohn's disease and ulcerative colitis in the United States . Clin Gastroenterol Hepatol. 2007, 5:1424-1429. 10.1016/j.cgh.2007.07.012

10. Targownik L, Bernsteinlow C, Nuggen Z, Leslie WD: Inflammatory bowel disease has a small effect on bone mineral density and risk for osteoporosis. Clin Gastroenterol Hepatol. 2013, 11:278-285. 10.1016/j.cgh.2012.10.022

11. Tjeerd V, Cooper C, Brusse L, Leufkens H, Javaid MK, Arden NK: Inflammatory bowel disease and the risk of fracture. Gastroenterology. 2003, 125:1591-1597. 10.1053/j.gastro.2003.09.027

12. Ferencz D, Li Pan, Hong L, Li Y, Wang O, Xing XP, Qian JM: Vitamin D levels and bone metabolism in Chinese adult patients with inflammatory bowel disease. J Dig Dis. 2014, 15:116-123. 10.1111/17512980.12118

13. Tsai MS, Lin CL, Tu YK, Lee PH, Kao CH: Risks and predictors of osteoporosis in patients with inflammatory bowel diseases in an Asian population: a nationwide population-based cohort study. Int J Clin Pract Suppl. 2015, 69:235-241. 10.1111/ijcp.12526

14. DerSimonian R, Laird N: Meta-analysis in clinical trials. Control Clin Trials. 1986, 7:177-178. 10.1016/01972456(86)90046-2

15. Higgins JP, Thompson SG, Deeks JJ, Altman DG: Measuring inconsistency in meta-analyses . BMJ. 2003, 327:557-560. 10.1136/bmj.327.7414.557

16. Bernstein CN, Blanchard JF, Leslie W, Wajda A, Nancy BY: The incidence of fracture among patients with inflammatory bowel disease: a population-based cohort study. Ann Intern Med. 2000, 133:795-799. 10.7326/0003-4819-133-10-200011210-00012

17. Sterne JAC, Gavaghan D, Egger M: Publication and related bias in meta-analysis: power of statistical tests and prevalence in the literature. J Clin Epidemiol. 2000, 53:1119-1129. 10.1016/S0895-4356(00)00242-0

18. Klaus J, Armbrecht G, Steinkamp M, et al.: Inflammatory bowel disease. High prevalence of osteoporotic vertebral fractures in patients with Crohn's disease. Gut. 2002, 51:654-658. 10.1136/gut.51.5.654

19. Sakellariou GT, Moschos J, Berberidis C, Mpoumponaris A, Kadis S, Molyvas E, Kouklakis G: Bone density in young males with recently diagnosed inflammatory bowel disease. Joint Bone Spine. 2006, 73:725-728. 10.1016/j.jbspin.2006.01.017

20. Canalis E: Mechanisms of glucocorticoid-induced osteoporosis . Curr Opin Rheumatol. 2003, 15:454-457. 